TRANS $\cdot$ núm. I3 $\cdot 2009$

DOSSIER $\cdot 33-41$
Este trabajo tiene como objeto estudiar la manera en que las obras de teatro transitan entre las distintas culturas. Analizamos la traducción de Romeo y Julieta realizada por Pablo Neruda como si fuese una nueva obra de teatro en la cultura meta. De esta forma el trabajo plantea cuestiones sobre la transferencia de la obra de teatro como un capital cultural y el impacto que tiene este hecho en la cultura de llegada. A manera de réplica, el ensayo indaga en la transferencia que se produce desde el contexto chileno a la comunidad internacional, preguntándose cómo traducir obras de teatro que evoquen el máximo grado cultural y proponiendo la idea de que la respuesta reside en el estudio de la poética teatral de cada obra. Por consiguiente, el proceso tiene la misma dinámica que la traducción de Shakespeare al español de Chile y el estudio del movimiento entre diferentes estructuras de sensibilidad nos permite adoptar un enfoque creativo en el estudio del tráfico cultural.

PalabRAS Clave: Obras clásicas, transmisión cultural, la nueva obra de teatro, estructura de sensibilidad, Neruda, Parra.

\title{
The Force of the Classics
} and the Challenge of
Cultural Extremity

This essay seeks to study the way in which plays move between cultures. By exploring Pablo Neruda's translation of Romeo and Juliet as a new play in the receiving culture. The essay poses questions about the transfer of the play as cultural capital and the impact this has on its place in the receiving culture. Counter to this, the essay looks at the transfer out of the Chilean context into the international community, asking how to translate plays that evoke cultural extremity and positing the idea that the answer lies in the study of the dramatic poetics of each play. The process then involves the same dynamic as the translation into Chilean Spanish of Shakespeare and the study of the movement between different structures of feeling allows us to embark on a creative approach to cultural traffic.

Catherine Boyle

KEYWORDS: classics, cultural transmission, the new play, structure King's College, Londres of feeling, Pablo Neruda, Nicanor Parra. 
Yo tengo una palabra en la garganta y no la suelto, y no me libro de ella aunque me empuja su empellón de sangre.

34

\section{THE FORCE OF THE CLASSICS}

When Pablo Neruda wrote Romeo y Julieta it was in 1964 for the four hundredth anniversary of the birth of Shakespeare for a production by the Instituto de Teatro de la Universidad de Chile (ITUCH), directed by Eugenio Guzmán, who had studied Shakespeare on a British Council grant to study with the Royal Shakespeare Company in Stratford-upon-Avon and on whose suggestion Neruda was approached. These cultural and historical contours form its shape. ITUCH is one of the university theatres that were created in Chile in the I940s with the express aim of creating 'un ambiente teatral', a theatre environment. The founders of this theatre movement, of which Eugenio Guzmán was one, sought to create a theatre space that would provide training through theatre schools, manufacture an audience through the introduction of quality international theatre, create 'hombres de teatro' prepared in all aspects of theatre craft, and provide a space for the emergence of a national dramaturgy. This was accompanied by a process of reflection, which found its way into publications that were a site for the dissemination of plays, for discussion and analysis on theatre activity and the sharing of ideas and practice. By the mid sixties the theatre environment was well established through these professional university theatres and Guzmán was a major figure.

The space for the performance, then, is vital. It is within a well established and financed University theatre that works professionally; it is at a time when the theatre in Chile is beginning to see the fruits of the innovations of the I940s;

it is situated in an intellectual environment that values the search for quality and the 'importing' of international drama; and it counts on the genius of the greatest living poet, Pablo Neruda, who would win the Nobel Prize in 1971. The project is gilded in the possibility of success and of transcendence. According to Guzmán:

Porque para poner en escena a Shakespeare en español no es suficiente el material trágico o cómico de sus obras, es necesario verter allí también el caudal luminoso de su poesía; sin ella, por atractivo que sea el espectáculo, Shakespeare deja de ser Shakespeare. Romeo y Julieta es por esencia una tragedia lírica, culta y refinada, a la vez que salvaje y vital, y en aquel entonces no existía en nuestro idioma una versión que le hiciera justicia (Guzmán, I979: 4).

Writing in 1979 (Neruda died in 1973 not long after the military coup), Guzmán calls 'every moment' with the poet 'un momento inolvidable' (1979: 5) and says that the work was considered by Neruda a real collaboration, though Guzmán says:

Lo único que yo realmente pude aportar a la labor de Neruda, fue mi fe entusiasta en que su lirismo se asemejaba asombrosamente al de Shakespeare y mi convicción de que en ambos vibraba a un mismo ritmo, a pesar de los diversos siglos, latitudes y verbo, ese encendido amor por el hombre y su incierto devenir que caracteriza la producción poética de uno y otro (Guzmán, I979: 5).

The production becomes a meeting of qualities, of those with serious cultural capital: Shakespeare (author), Neruda (the creator of the text), Guzmán (director), ITUCH (actors), audience. It will become a cultural event: the moment when the genius of Shakespeare will be matched in the Spanish language - and in Chile - by the genius of one of the greatest living poets and an already iconic figure in 
Chile as a voice of the people (poetically and politically, being a Communist Senator). It will be the moment when the instability of Shakespeare in Spanish will be resolved through a stable text to match the original. (It should be noted that in principle this was the aim of the RSC in the Spanish Golden Age Season - to use 'great writers' to match the original.) Yet, if Neruda sought to be 'estrictamente fiel a la poesía de Shakespeare' as well as to his dramatic expression (Guzmán, I979: 6), then this did not exclude the possibility — seen as the necessity - to cut the Spanish, to stop the Spanish 'overflowing' and creating an overly long play, a point of debate between the poet, the director and the actors:

Constantemente polemizábamos y nos poníamos de acuerdo sobre la necesidad de cortar parlamentos reiterativos, giros idiomáticos intraducibles, alusiones a hechos locales sin significación alguna para nuestro público o excesos culteranos. En honor a la verdad, debo confesar que el poeta era más proclive que yo a abreviar escenas. En ciertos momentos debí luchar, secundado por dos actores del reparto, Tennyson Ferrada y Franklin Caicedo, para resucitar a la versión, parte del famoso parlamento de Mercuccio, que alude a la Reina Mab (Escena IV, Acto I), que no sé por qué secreta razón tendía a fastidiar a nuestro poeta (Guzmán, I979: 6).

Neruda's own comments on the translation are not recorded (to my knowledge) other than a few remarks on the effort of matching the virtuosity of Shakespeare, on his use of the hendecasyllable for poetic fluency in Spanish, the process of research that the endeavour meant over five months in which he didn't write his own poetry, and his conviction that he would never try to translate Shakespeare again. But I want to pick up one last observation of Guzmán's in order to suggest a series of ideas:
Y nunca dejó de tener en cuenta que el autor se dirigía en sus obras a públicos de diversos niveles sociales y de muy diferente capacidad intelectual. Por ello evocaba en su versión algo de la poesía preciosista del español Góngora, mezclada a las crudas palabras del realismo cervantino. No hay duda que nuestro poeta logró conservar tales alternancias, manteniendo además en estricta prosa toda la prosa del texto original (Guzmán, I979: 6-8).

Neruda's offering is a gift to the Spanish language and to the Chilean people, the commentators seem to say, and the company managed to appreciate this and present something worthy of the poetry of Neruda, which allows us to hear Shakespeare, as critic said, 'en toda su pureza'

Felizmente, la dirección de Eugenio Guzmán permite oír la palabra poética, gracias a un buen equilibiro entre la acción, los parlamentos y las pausas, y una mejor dicción, si comparamos con otros casos. Aunque la garganta chilena es más bien enemiga de estas precisiones (Lefebvre, I979: 15).

The 'Chilean throat' is blamed for many evils in the world of translating and the stage, but we will return to that.

The poetics into which Neruda writes his Romeo y Julieta is one that is infused by but also eschews the popular poetics that have kept alive the voice and the echoes of Góngora through romances, décimas, and poetic duels, payas. Unlike many cultures, access to these rhythms and languages remains, if only in tenuous ways, but certainly guarded by the popular poet. Which makes Neruda's language even more interesting: the verbal jousting of which Mercutio is a master 'que no sé por qué secreta razón tendía a fastidiar a nuestro poeta', as we have heard Guzmán say, yet there would be ears for it in audiences in Chile, though perhaps not the Santiago elite that would form 
the audience for this production. Neruda brings Shakespeare into a poetics that shapes and roots the original, that centres it in a series of recognised written poetic forms, and he uses his own favoured hendecasyllable, with its resonances of the iambic pentameter. He distils the narrative of the play, favouring the lovers' story, their battle against socially imprisoning norms and inherited battles, and poignantly translates the languages that evoke the pain of exile (he was a political exile and runaway). And there is a hint of a puritanical thrust to the bowdlerisation of, particularly, the Nurse's speeches. The world he constructs is, perhaps unsurprisingly, Neruda's poetic world, and as such it highlights important tensions with the popular poetics of his time, tensions that would be played out in the other cultural expressions that appropriated the popular as a mark of political and national identity.

There was a 'revival' Romeo y Julieta in 1978 by the Teatro Itinerante under the direction of Fernando González and choreographed by Andrés Pérez. This was a young touring theatre company that used the elements of poor theatre to create what was for them a new performative theatre language 'en que la palabra fuera un medio de comunicación entre muchos otros tan elocuentes como ella' (González, I979: II):

«Romeo y Julieta, Hoy Ensayo» es el título que habría reflejado con mayor claridad el espíritu de nuestra versión libre para la obra de Williams [sic] Shakespeare, basada en la traducción de Pablo Neruda.

Esta versión libre no fue en absoluto antojadiza, ni buscando lo nuevo por lo nuevo. Fue el resultado natural de un acercamiento humano, espiritual y artístico a la permanente contemporaneidad de Shakespeare. Nuestro montaje es el espontáneo resultado de dos características del Teatro Itinerante. Por un lado, el

hecho de ser una compañía en gira y, por otro, la similitud de puntos de vista sustentados por los miembros de la compañía frente a la práctica del arte teatral (González, I979: 8).

The production is set in the context of the early years of the dictatorship, when theatre companies were trying to create threads of continuity with practices from pre-coup moment, while seeking to find the infamous and well known voice that speaks without speaking. That is, use, among other things, the classics as a means of speaking. So, Neruda is emblematic in this sense - his voice an iconic voice from the recent political and poetic past whose genius is an indigenous match for Shakespeare, and, significantly, HIS Romeo y Julieta has already carved out a meaning in the new play, one to which the new company, on the other side of the parenthesis of history marked by the IIth of September I973, is alive and is keen to exploit, following two other iconic figures in the pursuit of poor theatre, Eugenio Barba and Jerzy Grotowski in order to prove that classical theatre 'nos muestra cómo somos ahora en perspectiva con nuestro ayer, y este ayer con nuestro ahora' [shows us how we are now in relation to our yesterday and this yesterday with our now] (González, I979: ıo):

La obra empezó a ser para mí la tragedia de los adolescentes enmudecidos que, al quebrantar el silencio impuesto, caían en la violencia suicida.

Al tener seguro que la meta de nuestro montaje (la premisa) era demostrar cómo la imposición opresora de algunos adultos conduce a la desgracia, ubicamos el conflicto de la obra en nuestra puesta en escena, como el enfrentamiento del Hombre y sus circunstancias.

Por sobre los contenidos psicológicos, la actuación fue encausada a resaltar, apoyándose en los conflictos argumentales, el plano poético e ideológico de la obra. Los adultos se 
dividieron en conductores dialogantes (Fray Lorenzo y el Ama) y en conductores impositivos (los padres y el príncipe). Los primeros definidos cotidiana y humanamente, y los segundos, como fríos mecanismos deshumanizados (González, I979: II).

The process is clear: the text - 'a desirable cultural good' in Aaltonen's configuration (2000: 8 ) - is brought into being in performance to meet the needs of the indigenous practitioner at a particular point, turning Romeo and Juliet into a 'new' experience marked by its ability to engage where 'reality is being formed' (Williams, I977: 132). Its nature as a rehearsal - 'Hoy ensaya' - speaks of the precarious nature of production in those years of dictatorship and the itinerant nature of the group states the aim of the practitioner to convey their reality 'at work, in the streets, in assembles' (Williams, I991: I7I). Their Romeo and Julieta reshapes Neruda's 'embed[ding] of the tragedy in power struggles' (Racz 2005: 86) in the light of a generation that is violently silenced by a dehumanising machine. 'Licence' is taken on the grounds of both the perception of Shakespeare in the English language - that the tradition of performance is not unbroken — and on the grounds that Neruda has already taken a giant first step by not employing period language: '¿por qué un hombre de teatro tendría que tener un espíritu arcaico al montar un espectáculo destinado al hombre de aquí y ahora?' (González, I979: Io). There is no doubt here that the play s borrowed cultural capital, and the subtext is one of absence of local drama that can speak of reality in public spaces to an audience that is not controllable. Importantly, the production reveals a series of traces from theatre practices in Chile and beyond, it heralds a young theatre movement that will seek to speak out publicly - literally in the street - about the impact of a brutalising dictatorship, and it will spawn a number of key actors, and directors who will create their own language of 'aquí y ahora'. The group has no doubt that the text, with the translation as an added layer - is theirs to adapt and turn into a version of a translation. Encased in the process is a belief that the classics are there to be brought into being in the new spirit at the service of the moment, and that this will be done through a type of dramaturgical enactment, based on the right of the great poets to re-write and re-shape and of the theatre practitioner to do the same. So, if Neruda will pull Shakespeare into his poetics, so will this and many other groups as they establish theatre languages that speak for their experience.

\section{THE CHALLENGE OF CULTURAL EXTREMITY}

The challenge of the perceived sense of cultural extremity is the key challenge of placing the theatre of Latin America (using Chilean drama as an example), for it is the challenge that will force the gaze beyond what can be easily known and stereotyped and marketed for international consumption because it does not challenge dominant views. In the example of the translation of the classics by the classics (great poets) a clear process is at play. It is largely one of desire: the desire to see the not yet fully expressed genius of Shakespeare brought alive in the craft of the poet who belongs to the local linguistic community. The movement is based on a sense of trust - at least in the linguistic re-enactment. What is brought into the target culture is a new play that the force of the recognised talent of the writer will act as guarantor; it may not be 'Shakespeare' after all, but it is still a crafted work of artistry of potential persistence. 
Its reading becomes possible because it has embedded itself into the new 'structure of feeling', to follow Raymond Williams phrase. Yet, this process is revealing of the ways in which the traffic of translation operates.

The impulse of Neruda and later Parra (Boyle, 2005) is to locate their translations locally, to create a coherent object that will be understood by their immediate audience in their immediate historical moment. Yet the experience of dramaturgy and of reception is radically different, as Williams highlights, talking of Elizabethan languages:

The common language, in fact, contains elements of literary precision and complexity. The otherwise startlingly incongruous elements of Elizabethan drama - its lowest naturalism and its highest conventionalism are given a working unity by this community of expression. Such a community of expression is not today the universally accessible tool but rather the very crown of very craftsmanship (Williams, 1964: 30).

The insight here is valuable in that it provides a way of thinking about translation within a linguistic community. Neruda embeds his translation in a long-evolving poetics, and one that was increasingly politicised in his later life. Nicanor Parra's 1992 translation of King Lear embeds his translation in his anti-poetry, using popular forms in iconoclastic ways that are disruptive of the elite forms in which they are written. So, Parra's linguistic community, his deliberate search for a poetry that oscillates 'la academia, la calle y la feria' (Hurtado, I99I-I992: 26) and finds its place in the midst of 'bullicio' that brings together 'circus, fairground and people' (Labra, I997, n.p.) mirrors a complex range of dramatic and poetic registers, using his own poetic structures that have been shaped by the emergence from the linguistic community of the popular poet and the creation of a linguistic community amongst the elite. So, Parra's poetic transcription of Lear is the creation of a new play that will purposefully set out to find its linguistic community in an already existing set of interlocutors, who might not be in the habit of sharing the same space. The result is a new play that is the 'very crown of craftsmanship' within a community of expression. And the individual nature of the craftsmanship allows for a forceful positioning of the play: one that is disruptive of attempts to place Shakespeare in hallowed ground. Written early in the period of the transition to democracy, El rey Lear becomes, among many other things, a poetic call for the memory and incorporation of all that has been marginalised as extraneous to dominant discourses, based often on a semantics of 'sanity' and tranquillity.

Yet, let us not forget 'la garganta chilena'. Parra had written Lear without punctuation in order to force the actors into thinking about meaning, rather than being guided into meaning. He told the actors to 'sin on the side of slowness rather than speed' and one commentator said that ' $[t]$ he delivery in Spanish becomes at times blurred, unclear and I wonder how much that is due to the way Chileans speak Spanish and if we will need to pay attention to that in the future' (Fassnidge, I99I-I992: 52 ), recalling, of course, the assertion that 'la garganta chilena es más bien enemiga de estas precisiones'. One obvious interpretation is that the acting community - those charged with embodying the language - is not ready, not prepared to enunciate, to perform the complex art of speaking the classics. This feeling of a certain lack of foundation is certainly an element when there no real tradition of performance and one keenly felt by that company. More important, though in this context, is the impact 
of this dynamic when it is not the classics that are stuck in the Chilean throat, but the new writing that cannot make its way beyond and into translation. If the perceived universality of the classics can be inserted into a local poetics and reality, the question remains: how can the local enter into the universal? The answer is, I think, by the same mechanism.

The question revolves around the translation out of a culture with less perceived cultural capital. I want to finish with a short commentary on the work of the Chilean dramatist Juan Radrigán, which is instructive in this respect, looking at a dramatic language that is potentially - and intentionally in the first instance — stuck in the 'Chilean throat': poorly enunciated, torrid violent, excluded and excluding. The dynamic in terms of translation is one of movement out of the writing of a dense linguistic community, whose goal is to bring the inarticulate into a space of articulacy. His works occupy a space of movement towards articulation: they introduce coherent but at the time largely invisible structures of feeling through a language that is to be found on the margins of semantic - and aural - accessibility.

The translation process is long and arduous; starting with the deciphering of the slang used and the morphological systems set up by Radrigán, followed by the iceberg versions of the translation that begin to allow meanings to emerge but that should never be seen, and proceeding to the moment of the decision of where the translated word comes into being. All of this is encased in the need for the translator / cultural mediator to understand and convey the context. Juan Radrigán calls himself a 'juntapalabrero' whose role is to collect and craft the words that fall from the mouths of the most dispossessed. While the location of performance of his plays has crossed, since his early plays in the 1970s, the shanty town, the university and professional theatre, international performances and translation, the challenge of the work remains that is evolves around a certain univocality. Cristián Opazo calls his writing «una cartografía de una ciudad 'invisible' aquel espacio imaginado que los desamparados sociales de nuestra urbe conciben como un 'refugio afectivo' donde guarecerse de la cesantía, la violencia y, sobre todo, el desamor» (Opazo, 2008: 104). Opazo locates the work both within and beyond political readings, seeing the plays as representing the attempts to create affective bonds out of destroyed communities. The language militantly presents this reality on stage, being hard to interpret even for Chileans a few miles from the initial site of enunciation. This is already a move from source to target cultural realities and the intention is for the target audience is to feel maligned:

Los personajes de Radrigán se apropian e imponen una forma discursiva, transformando la escritura y poniéndola en un lugar que le otorga representación como una forma de resistencia que documenta un estilo de vida, una historia personal, una forma de existir particular antes no reconocida en el modelo cultural dominante (Luengo, 1999: 70).

Luengo sees Radrigán as transgressing literary tradition in order to incorporar en su dominio la voz del otro, ya no como una dócil cámara de eco, sino más bien como un modo expresivo desprendido de un sistema de presuposiciones y creencias sistemáticamente organizados por el cuerpo social que le subyuga y le es ajeno' (Luengo, ib.: 7 7 I).

This is at the core of the translating experience. The goal is to for the translation to be something more that an 'echo chamber'. The goal is to insert the play in a new structure of feeling, where it will be lived through 
'meanings and values as they are actively lived and felt' (Williams, I977: 132). And, in the case of a dramatist like Juan Radrigán, the question 40 is whether this same disruptive effect can be created: will the new play possess the same potential disruptive drive and power, which is what, in many cases, will drive the translation in the first place. The play is, in Pavis's term, being drawn towards the target culture, where it is being 'bombard[ed] with questions from the target language's point of view: positioned here where I am, in the final situation of reception, and within the bounds of this other language, the target language, what do you mean to me or to us?' (Pavis, I992: 138). In the process of understanding the play for translation we look for its significance 'in the original'. Yet, the reality is that this significance has already been splintered: the play has not meant just one thing in the original, no matter how much the playwright had a particular intention in a particular historical moment. And, for example, the transgressive impulse of the original may not translate from the source to the new target.

Yet, there is something very strong and simple at the core of this process. The act of translation already suggests that there is a story to be told, for translation will always be very simply about a set of core questions: what stories do you have that we want to tell? And also what ways of telling stories do you have that we would like to borrow? It is a question of desire; the longing to tell the discovered story. The study of the complexities and the fracturing of spaces in the source culture functions more as an understanding of that culture and its expression — its coming into being — in the work of art. The significance of the source culture for the target comes into crisis - and it always will. Its place and relevance splinters as it moves, for the process of moving is not from one specific one-dimensional space to another specific one-dimensional space, but from an accumulation and negotiation of spaces into other sets of accumulation and negotiations of spaces. Then it splinters again in the processes of understanding in the new language. And while cultural understanding of a source culture is called upon as 'background information' - in order the respond to basic questions of understanding, to the central hermeneutic act (Pavis, I992: 138) of translation - it is also abandoned so that the story can be told again responding to the target.

For, the answer to the translation of plays such as these, which deal with seemingly alien forms of cultural extremity, is to treat them as we might a Shakespeare: to enter into their poetics and trust in their robustness beyond a single meaning. For if they are to be translated and fulfil the desire to hear new stories and therefore to pose different questions of experience or to help the target culture in articulating new experiences, they must have a central robustness. In the hermeneutic act of translation - where all sorts of secrets will be yielded - the cultural mediator will, crucially, acquire different memories of the play. One will be 'macrotextual', as Pavis might say (I992: 139) allowing us to contextualise, to create a type for radar for the languages that inform the drama. The other is the internal memory of the play that will feed the understanding of the poetics. This allows the translator to come close to the layers of meaning in the original, it allows both literalness and freedom: the literal in the ability to 'match the fragments of the vessel', to paraphrase Benjamin (I999: 79); the freedom in the rendering of meanings that have already been set in the intention of the original. Yet, what may be an imperative driven by the historicised force of what 'has happened here' in the source 
culture as Radrigán would often say, becomes judged by a different set of historical / cultural / aesthetic criteria in the target literature and culture, and because of that there is a decreasing sense of, for example, political contingency. In that respect, the cultural translation and transmission are set in a different perspective: the written word does not figure as a univocal source that enunciates the experiences of the inarticulate and disarticulated: instead it can be seen and heard moving in a community of people voices, experiences and memory. And the new play takes on the potential of becoming new again its source culture, evoking Benjamin's 'eternal renovation of language' (1999: 75).

RECIBIDO DICEMBRE 2008 ACEPTADO FEBRERO 2009

\section{REFERENCES}

Aaltonen, S. (2000). Time-sharing on Stage. Drama in Theatre and Society, Clevedon: Multilingual Matters.

Benjamin, W. (1999). Illuminations, H. Arendt (ed.), London: Pimlico.

Boyle, C. (2005). 'Nicanor Parra's Transcription of King Lear: The Transfiguration of the Literary Composition', in B. Kliman and R. Santos (eds.) Latin American Shakespeares, Madison, Teaneack: Fairleigh Dickinson University Press, pp. II2-I29.
Fassnidge, C. (I99I-1992). 'Diario de una producción', Apuntes, I03, pp. 48-65.

Gibbons, B. (ed.) (I980). William Shakespeare: Romeo and Juliet, Walton-on-Thames: The Arden Shakespeare.

González, F. (I979). 'Romeo y Julieta. Hoy Ensayo', Cuadernos de Teatro, I, pp. 8-II.

Guzmán, E. (1979). 'Shakespeare en alas de Neruda', Cuadernos de Teatro, I, pp. 4-7.

Hurtado, M. L. (I99I-I992). 'Parra Traduce a Shakespeare', Apuntes, Io3, pp. 23-35.

Labra, P. (1977). 'Hojas de Parra', El cronista, 27, February.

Lefebvre, A. (I979). 'Romeo y Julieta', Cuadernos de Teatro, I, pp. I5-I9.

Luengo, E. (I999). 'Poder, resistencia y reacción en Hechos consumados de Juan Radrigán', Latin American Theatre Review, pp. 69-86.

Neruda, P. (1966). Romeo y Julieta, Buenos Aires: Losada.

Opazo, C. (2008). 'Juan Radrigán: Una poética urbana', in C. Oyarzún (ed.) Juan Radrigán, Ediciones Pontificia Universidad Católica de Chile, pp. IO3-I27.

Pavis, P. (1992). Theatre at the Crossroads of Culture, London: Routledge.

Racz, G. J. (2005). 'Pablo Neruda's Romeo y Julieta', in B. Kliman and R. Santos (eds.) Latin American Shakespeares, Madison. Teaneack: Fairleigh Dickinson Press, pp. 7I-9I.

Sepúlveda, F. (I99I-I992). 'El Rey Lear de Nicanor Parra', Apuntes, Io3, pp. 36-43.

Williams, R. (I964). Drama from Ibsen to Eliot, London: Penguin.

Williams, R. (I977). Marxism and Literature, Oxford: Oxford University Press.

Williams, R. (I99I). Drama in Performance, Milton Keynes: Open University Press. 